\title{
Carta de amor
}

\author{
Alcides Villaça
}


Dei por ela já na letra da primeira carta.

É sabido que, muito antes das palavras, é a letra pessoal que desenha todos os significados essenciais, aqueles que os olhos recolhem diretamente, sem precisão de idioma ou dicionário.

A carta era para mim, as palavras desenhavam-se para mim, tanto quanto a letra era inteiramente dela, espelho fidedigno onde com método ela se arrumava e se enxergava a cada vez que escrevia. Seus dedos, que adquiriram instrução própria, queriam mais saber e dizer, e o faziam propondo linhas e sinuosidades incontáveis, num desenho que corria com aquela força e aquela autonomia que falam e assinam por si.

Estava condensado nos contornos da letra o sentido fundo da curta mensagem, alvoroçando minha tarde que ameaçara ser igualzinha a tantas e tantas outras que passo nesta sala de algum trabalho e muita distração. Que a carta viesse de onde vinha já era estranho, pois não conhecia ninguém daquela cidade, e nem de longe o nome da remetente. Isso já era um evento espetacular em meio à rotina da minha mesa com as gavetas cheias de manuscritos muito lidos ou exercitados.

Certa vez uma escritora, celebrada na roda dos leitores comuns, me disse que os detalhes mais prosaicos são essenciais na prosa, que é preciso costurar fatos e pessoas, e que eu tinha de me livrar daquela obsessão confiante pela letra 
manuscrita, pelos desenhos caligráficos, pelo ritmo do pulso, se quisesse escrever alguma história digna do nome. Mas preferi atender minha vocação para outras histórias, como esta, sem no entanto jogar fora de todo aquele conselho - tanto que passo a vos informar que: a) sou professor de literatura; b) ocupo, portanto, um específico e singular degrau da classe média; c) tenho um escaninho (com chave) para a correspondência; d) foi dele que, naquela tarde, retirei a dita carta; e) tendo em seguida subido até minha sala, onde passo as tardes; f) as quais costumam ser demoradas e contemplativas, entre as inscrições e os experimentos do meu ofício.

Era morno meu estado de espírito, antes que meus olhos se agitassem com a letra do envelope, logo em seguida aberto - pois já o sobrescrito anunciava um convite urgente para o início de uma grande paixão. E era. Li isso em cada variado pingo de $i$, em cada voluta de $v$, em cada derramado $m$, sobretudo se seguido de $u$ e $n$, como em mundo, nome que ali desenhava uma ondulação contínua com vibração íntima e nervosa - mas logo controlada por um travessão cortante e cheio de respiração. Nossa profissão nos deixa espertos, com este olhar aplicado às letras, escavando-as tanto que o assim chamado sentido das palavras e frases se conforma a seu papel secundário, de desprezível relevância. Com esse treino, tornamo-nos especialistas na operação de surpreender, por diligência analítica e dirigida sensibilidade, o passo antes da intenção, o motivo antes do movimento, a fala anterior, interior e posterior à suposta mensagem.

Passei em seguida, com tédio, a ler convencionalmente as palavras, em suas vagas indicações. Pouco vos direi delas, pois nem de longe serviam à verdade que eu já decifrara com segurança no formato expressivo das inscrições. Era uma carta de amor, não havia dúvida, disfarçada num pedido de informação que uma estranha dirigia a um estranho, a propósito de um estranho livro que, estranhamente, ninguém, além dela, havia admirado.

Conhecia-o eu, que o havia escrito e que o esconjurara desde que o manuscrito passara pela máquina de escrever de alguém, de onde saiu para uma gráfica e, como última aberração, se imprimira e se distribuíra por algumas livrarias. Aquela coleção de poemas custosamente desenhados em muitas tardes vagas, ao longo de anos e anos de sala, fora toda apagada pela esterilidade da escrita industrial. Naquele tempo, eu não suspeitava da extensão desse assassínio tipográfico, do 
alcance dessa traição. Quando vi, era tarde, e fiquei meses e meses sem desenhar de próprio punho qualquer palavra, voltado inteiramente para a minha tarefa principal - qual seja, a de surpreender, sob o tom e a derivação do assunto aparente, o motivo original de cada autor de letras, sobre as quais ainda não se erigira a lápide da impressão mecânica ou eletrônica. Tenho certeza de que se um dia cometerem a insanidade de submeter este manuscrito a tal insídia, havereis, alguns de vós, de me vingar plenamente, buscando-me e adivinhando-me vivo nesta caligrafia original e nestes arabescos essenciais, traçados por meus dedos. Respondi imediatamente à carta, como bom profissional, imprimindo uma confidência a cada toque do lápis, entremeando as inscrições com precisos espaços, variados conforme a transposição do fôlego. Resultou um dos meus melhores inscritos, cada parte levando ao todo, o todo supondo cada parte, tudo integrado num aspecto denso e orgânico, ao qual não faltou sequer, sob a filigrana da assinatura, o requinte de um P. S. seguido de nada, qual uma fermata na pauta de uma sonatina. Não me lembro exatamente o que pretextavam as palavras casuais; creio que me vali de assuntos variados, como a carestia, a questão das patentes e a já iminente decisão do campeonato paulista.

Passaram-se semanas sem qualquer outra alteração na rota. $O$ curso do semestre já ia pelo fim, e eu receberia dos alunos uma tonelada de manuscritos para avaliar. Com muita aplicação entortava eu uma curva aqui, desentortava outra, refazia um segmento de desenho, apagava um traço morto, para anular o intervalo entre a intenção e o gesto. Em certos casos, era impossível: o adestramento automatizado dos dedos deixava subentendida a odiosa digitação mecânica, que se mostrava uniformizando por si o aspecto mais pessoal da letra e tentando remeter o leitor ao famigerado sentido daquelas palavras vazias. Tempos bárbaros.

Mas um dia abri o escaninho e outra carta - agora mais que familiar - se apresentou, sempre a lápis número 2 bem apontado, tão coerente e clara como a primeira. Não fosse a ansiedade humana, eu não teria por que correr a abri-la, sabendo, já pelo sobrescrito, a doce matéria que na folha se abriria. O pretexto de suas palavras era algum desconcerto com minha resposta, que ela fingia não entender, supondo mesmo que eu houvesse trocado envelopes e remetido a ela o que seria de outrem. Reforçava, ainda, as mesmas palavras pretextuais da carta anterior, solicitando agora uma resposta objetiva e bem endereçada... 
Encantou-me tanta malícia. A sensualidade da letra fora levemente reprimida, passando agora um recado ainda mais subliminar e fino, que seduziu por completo meus olhos de expert. A sutil censura alargava o calibre de emoção do desenho todo, que em alguns trechos chegou a me excitar a vista, quase confundindo minha interpretação. Tratava-se, é claro, de uma profissional. Em anos de magistério superior aplicado, aprendi a reconhecer a mestria desses talentos que dissimulam para melhor expor, que deixam de cortar um $t$ só pelo torneio a que nos obriga um $l$ remissivo, que deixam de virgular para que busquemos a pausa no espaço que se transpôs para a frase seguinte e para que - nesse deslocamento dos olhos - surpreendamos a volubilidade ubíqua do sujeito, critério do traço que conduz todo o desenho.

Tratava-se de uma profissional. Em seu rastro pelo papel passei a divisar seu retrato físico e biográfico, além do evidente retrato moral. Era de meia-altura, clara, olhos verdes, gestos delicados em contraste com a voz decidida. Habitara entre pinheiros, na infância, que tivera que deixar em troca da cidade inevitável, levando-os, porém, nos olhos, e inscrevendo-os no papel, sempre que podia. Era tímida mas enérgica, resoluta mas doce.

Passei horas em resposta. Precisava corresponder àquele nível de talento, valendome do que aperfeiçoara em anos e anos de prática e leitura de traços disciplinados. Superei em expressão minha primeira resposta. Buscando ser o mais eficaz possível quanto ao caráter pretextual das palavras, copiei uma receita de canapé de um jornal e um poema concreto de uma revista acadêmica, para não deixar dúvida quanto à ênfase em outras direções a serem buscadas no caminho das letras e sinais, que - diga-se de passagem, e sem modéstia - atingiam ali a excelência da escrituração. Os traços eram moldes que chamavam os olhos dela para que os habitassem, que se preencheriam à medida que seu olhar os acompanhasse com precisão, acrescendo-lhes a massa de luz e sombra premeditadas. Jamais conseguira eu tanta ênfase com o jogo de súbitas maiúsculas, com incisivas reticências e um desnorteante manuseio de barras, com o qual simulava uma citação de versos. Seus olhos espertos recolheriam aquelas confissōes no mesmo calor com que eu as produzira.

Dessa vez sua resposta veio rápido. A princípio nem dei por ela, quando apanhei com relutância um envelope datilografado, com aquele ar estúpido e invasivo de 
mala direta. Lendo atrás o nome da remetente, agora em manuscrito, caí em mim e tive de sentar ali mesmo, no saguão do prédio. Levei enfim o envelope para a minha sala, confuso, desnorteado, cogitando se encontraria na carta algum desdobramento daquele inexplicável insulto datilografado.

Que nada. A pérfida fizera bater-me o coração na porta de fora só para que dentro da casa a surpreendesse mais inteira e nua do que nunca. Era um festim de letras miniaturizadas em diversos calibres de grafite, uma orgia quase explícita de sombreamentos oblongos, uma semitonalidade despudorada em vogais-semifusas. Como não me perturbar com aquela pauta? Pensei em como responder àquele plus non ultra da amiga minha, da amante minha, depois que recobrasse o controle das mãos trêmulas.

Dessa resposta, amigos, jamais fui capaz: rendi-me ao seu avassalador talento natural, o maior, que nem mesmo um Aristóteles teria sabido regrar. Já notara eu que um corpo feminino era uma falsa geometria, dessas que acentuam o caráter de promessa e de rascunho quando já são a experiência e a prova definitiva de um caos magistralmente construído. Aquela carta era a nudez completa, indo do traço ao silêncio e do silêncio ao traço, numa caminhada perfeitamente imitativa dos pés em seta, dos cílios úmidos, da nuvem pela janela - quase diria: da tepidez da tarde.

Guardo-a na gaveta, olho-a às vezes. Joguei fora as anteriores, definitivamente superadas por esta: na comparação, aquelas pareciam meros exercícios, que esta totalizou com absoluta perfeição. É a minha consolação suprema. Basta que me assalte o medo do tédio, a desconfiança de que um mito é apenas fumaça num espelho retrovisor, de que o futuro é pouco mais que um exercício para o salto de trampolim - bastam esses avisos para que eu abra a gaveta, me deixe surpreender com o envelope e chegue à epifania máxima daquela letra, que me excita sempre, que me faz viver, que me prova vivo, que é a edição mais sensual do limite amoroso das criaturas. 